\title{
The Contribution of Learning Outcomes for Listening to Creative Thinking Skills
}

\author{
Ebru Aldig $^{1}$ \& Ayla Arseven ${ }^{2}$ \\ ${ }^{1}$ Ministry of Education, Sivas, Turkey \\ ${ }^{2}$ Faculty of Education, Cumhuriyet University, Sivas, Turkey \\ Correspondence: Ayla Arseven, Department of Primary Education, Faculty of Education, Cumhuriyet University, \\ Sivas, Turkey. E-mail: aylaarseven2004@yahoo.com
}

Received: January 9, 2017

Accepted: February 21, 2017

Online Published: March 15, 2017

doi:10.5539/jel.v6n3p41

URL: http://doi.org/10.5539/jel.v6n3p41

\begin{abstract}
This study aims to examine teacher's opinions on the contribution of learning outcomes for listening defined in the Ministry of National Education's Turkish course curriculum for the $6^{\text {th }}, 7^{\text {th }}$ and $8^{\text {th }}$ grades to the development of creative thinking skills. Mixed methods research design was adopted in the study. As the quantitative part of the study, a questionnaire titled "Assessment of learning outcomes for listening" was prepared by the researcher and administered to 150 Turkish teachers working at 35 different schools. Interviews were held with 13 teachers about the contribution of learning outcomes for listening to the development of creative thinking skills. The quantitative data obtained from the interviews were analyzed using the content analysis method. The analysis was conducted using frequencies, arithmetic means and the Chi-Square test.

The findings of the study revealed that the learning outcomes for listening defined in the secondary Turkish course curriculum contributed to the development of creative thinking skills of students. The gender, seniority, alma mater and educational background of the teachers did not change the results. As a result of the interviews, four categories were identified: "listening outcomes and creativity", "creative thinking", "readiness level of students" and "development of thinking skills".
\end{abstract}

Keywords: creative thinking, learning outcomes for listening, Turkish course curriculum

\section{Introduction}

A curriculum based on constructivism is designed in a way to ensure permanent learning and to develop high level cognitive skills (Şaşan, 2002). The purpose of constructivist education is to encourage students to make research and to develop their thinking skills. Learning does not involve receiving a defined cluster of transferred information, but helping learners gain effective learning, deduction, problem solving and learning skills (Alkan et al., 1995). According to Özbay (2009), "Understanding the information communicated verbally or in written is an important skill that students need to gain". Understanding is one of the basic steps of the communication process. At schools, students need to gain competence in learning the information they need, in other words the competence of learning to learn. The role of education is to help students learn the real world, while the role of teachers is to interpret the events (Özden, 2000). The way to teaching to learn is through four basic language skills: reading, listening, speaking and writing. The activities designed based on these skills are also important for students. The most important point to know is whether the learning outcomes of a course have a positive impact on the lives of students, or not. The way to understand this is to examine the relationship between creative thinking skills and the learning outcomes for listening defined in the guidebooks. Creativity involves flexible, original, fluent and novel thinking (Senemoğlu, 2001). In today's ever changing world, it is an obligation for individuals to be equipped with skills adaptive to new situations. Therefore, every country needs individuals with high perception who will be able to move the country to the next generations, use information properly, generate information, express their problems and create different solutions to them (Tekin \& Taşgın, 2008).

Education is based on values which are so independent that they cannot be narrowed down to the mere transfer of information to students. What matters is not the efforts made by the students to make sense of the concepts 
that form information by means of instructions, but their ability to perceive the real meaning behind the concepts (Özel \& Bayındır, 2008). A constructivist approach allows students (MEB, 2009, p. 146);

- To investigate, examine, question and make sense of information,

- To integrate new knowledge into their existing knowledge and restructure the content of the knowledge in their mind,

- To develop linguistic and mental skills and to continue learning.

Therefore, students do not directly receive knowledge, but try to reach that knowledge, and when they have reached, they are able to understand and interpret it. This shows us once more the importance of the Turkish course. A student who fails in reading comprehension and interpretation cannot be expected to be successful at school. Similarly, those relying on rote learning instead of inquiry-based learning cannot be successful in the long term. One of the primary objectives of constructivist education is to raise students who can reach knowledge and make comments on them, instead of directly receiving such knowledge. Constructivist education helps students think in a multidimensional way, and knowledge is given to students under the guidance of teachers (Erdem \& Demirel, 2002). The main objective of language teaching is to help students comprehend the language in different contexts, express themselves by means of that language, reach different sources of information and enrich their world of sentiments, thoughts and imaginations (MEB, 2006, p. 2).

Today's constructivist language teaching approach emerged as a result of the studies by the language experts such as Piaget, Vygotsky and Bruner. This approach is based on the learning and mental skills of individuals (Güneş, 2011). Development of thinking skills is an important factor in helping individuals achieve success in both their social life and learning life. People with developed thinking skills are useful for both themselves and their environment. Thus, we need to attach importance to the development of thinking skills. Those who are aware of this have begun to give due importance to thinking skills in language training.

The language we teach must help children perceive their environment easily, and language teaching must be performed in a way to help children communicate easily (Ünalan, 2001). From this point of view, we can say that students need additional skills to express themselves, to take a place in society and to achieve effective communication. These skills are defined as "Basic Skills" in the Turkish Course Curriculum (2006). Creative thinking skills are among these skills.

Creativity is an ability that every single individual has and that could be found in all parts of human life; a compound of processes, from daily life activities to scientific fields; and a style of manner and behavior (San, 1979). Based on this definition, we can say that creative thinking has an important place in our lives. Individuals must know how to think creatively in order to improve themselves and to be beneficial to other people, because creativity is found in every individual and what matters is to reveal it. Here, the responsibility is on the trainers. Today's education system aims that students do not receive information directly, but try to reach it. Students must think in a multidimensional way, avoid looking at the events from a one-sided perspective and create new things. Teachers must know their students and design individualized programs appropriate to the students' interest and developmental characteristics (Yenilmez, 2007).

\section{Aim}

This study primarily aims to examine the teachers' opinions on the contribution of learning outcomes for listening defined in the Turkish course curriculum for the $6^{\text {th }}, 7^{\text {th }}$ and $8^{\text {th }}$ grades to the development creative thinking skills. It also aims to find out how the Turkish course curriculum affects the learning process and to assess the learning outcomes in terms of thinking skills. In this study, we sought answers to the following research questions:

1) What are the opinions of Turkish teachers on the relationship between creative thinking skills and the learning outcomes for listening defined in the MoNE Turkish course curriculum for the $6^{\text {th }}, 7^{\text {th }}$ and $8^{\text {th }}$ grades?

2) Do the opinions of Turkish teachers on the contribution of learning outcomes for listening defined in the MoNE Turkish course curriculum for the $6^{\text {th }}, 7^{\text {th }}$ and $8^{\text {th }}$ grades to the development of creative thinking skills change depending on:
a. Gender,
b. Seniority,
c. Alma Mater,
d. Educational background? 
3) What are Turkish teachers' opinions on the contribution of learning outcomes for listening defined in the MoNE Turkish course curriculum for the $6^{\text {th }}, 7^{\text {th }}$ and $8^{\text {th }}$ grades to the creative thinking skills?

\section{Methodology}

This study was conducted using a mixed-methods design which includes both quantitative and qualitative research methods. The quantitative data were reinforced by the qualitative data. As the quantitative part of the study, a questionnaire titled "assessment of learning outcomes for listening defined in the Turkish course curriculum for the $6^{\text {th }}, 7^{\text {th }}$ and $8^{\text {th }}$ grades" was prepared by the researcher and administered to the participants. The quantitative part of the study was conducted using the descriptive survey model which is a research approach aiming to describe a past or currently existing situation as it was there and trying to define an event, individual or object of research subject within their own conditions and as are/were (Karasar, 2002). In the qualitative part, focus group interviews were used. Qualitative research is a research approach which is based on induction and focuses on describing events and phenomena in their own natural environment as well as understanding and reflecting the viewpoints of participants (Yıldırım \& Simşek, 2006).

\subsection{Population and Sample}

The population of the study consisted of 240 Turkish teachers working at 48 different secondary schools in Sivas city center (excluding villages and towns) under the Ministry of National Education in the 2015-2016 academic year. Based on the population, 150 Turkish teachers working at 35 different schools in Sivas city center were chosen through "simple random sampling". The interview method developed by the researchers was used to collect qualitative data. 13 teachers (6 were female, 7 were male) from 5 different schools were chosen as the study group by "easily accessible sampling". Table 1 shows the distribution of the participants by different variables (gender, seniority, alma mater, educational background).

Table 1. Distribution of the participants by different variables (gender, seniority, alma mater, educational background)

\begin{tabular}{lcc}
\hline Alma Mater & f & $\mathbf{\%}$ \\
\hline Turkish Language Teaching & 84 & 56.0 \\
Turkish Language and Literature Teaching & 14 & 9.3 \\
Turkish Language and Literature & 52 & 34.7 \\
Gender & 79 & 52.7 \\
Female & 79 & 52.7 \\
Male & 71 & 47.3 \\
Length of Service & & 18 \\
$1-5$ years & 28 & 43.3 \\
6-15 years & 65 & 38.0 \\
16 years and above & 57 & 91.3 \\
Educational Background & & 8.7 \\
Undergraduate & 137 & 13 \\
Graduate & & \\
\hline
\end{tabular}

According to Table 1, out of 150 participants, 56\% were the graduates of Turkish Language Teaching, 9.3\% were the graduates of Turkish Language and Literature Teaching and $34.7 \%$ were the graduates of Turkish Language and Literature. Most of the participants were the graduates of Turkish language teaching. Of all these participants, $52.7 \%$ were male and $47.3 \%$ were female. The numbers of females and males were similar; however, the number of females was a little higher than that of males.

Table 1 shows that, out of 150 participants, $18.7 \%$ completed 1 to 5 years of service, $43.3 \%$ completed 6 to 15 years of service and $38 \%$ completed 16 years and above in service. The findings show that the number of teachers with 6 to 15 years of service is higher than the number of the other teachers. The reason may be that the 
study was conducted mostly in the city center, thus the participants had already served at different places before they were assigned to the city center.

Table 1 also shows that $8.7 \%$ of the teachers had a graduate degree, while $91.3 \%$ had an undergraduate degree. We can say that the number of teachers with a graduate degree is less than those with an undergraduate degree.

\subsection{Data Collection}

Following the literature review conducted by the researcher, 42 learning outcomes defined in the MoNE Turkish course curriculum (2006) were used to prepare a questionnaire. The questionnaire was submitted to the opinion of three experts. Following the administration of the questionnaire, interviews were held with the participants to see whether the results were consistent with each other.

The 5-column 4-space approach was adopted in order to determine the range of arithmetic means. The range was found to be $4 / 5=0.8$. It was interpreted as follows:

1.00-1.79: Strongly disagree

\subsection{0-2.59: Disagree}

2.60-3.39: Neutral

3.40-4.19: Agree

4.20-5.00: Strongly Agree

As a result of the analysis of 42 outcomes, the Cronbach's Alpha reliability coefficient ( $\alpha$ ) of the questionnaire was found to be 0.968 .

As a result of the literature review, a semi-structured "teacher interview form" was designed by the researcher to be used in the qualitative part of the study. The form was submitted to the opinion of three faculty members specialized in Turkish language teaching and educational sciences from the Faculty of Education of Cumhuriyet University. The form was revised based on criticisms and recommendations. The semi-structured interview form was pre-administered to 5 teachers not included in the study group and the items were revised into final form. One of the five questions on the interview form was as follows:

1) What do you think about the effect of learning outcomes for listening defined in the Turkish course curriculum for the $6^{\text {th }}, 7^{\text {th }}$ and $8^{\text {th }}$ grades on the development of creative thinking skills of the students?

- Are there any outcomes for coming up with a new product? Please explain?

- Do you think listening outcomes can help students improve their skills of thinking differently and breaking down prejudices? Please explain?

- Do you think students can think flexibly and improve their ability of synthesis by means of the listening outcomes? Please explain?

- Are there any outcomes that will arouse students' curiosity and encourage them to investigate? Please explain?

The questionnaire titled "Assessment of Learning Outcomes for Listening Defined in the Turkish Course Curriculum" was used to collect quantitative data. The questionnaire was administered at 35 secondary schools in Sivas and its districts under the Ministry of National Education in February and March 2016. The qualitative data were collected in the spring semester of the 2015-2016 academic year. To prevent data loss, a record device was used during the interviews. Attention was paid to provide an environment in which the participants could feel comfortable and relaxed and express their opinions freely. A suitable interaction environment was provided.

\subsection{Data Analysis}

The data obtained from the questionnaire "Assessment of Learning Outcomes for Listening Defined in the Turkish Course Curriculum" were analyzed using SPSS Statistics 23. The data analysis was conducted using frequencies, arithmetic means, percentages and the Chi-Square test. The quantitative data obtained through the "Teacher Interview Form" were analyzed using the content analysis method.

\section{Findings and Interpretation}

\subsection{Findings of the Quantitative Data}

Table 2 shows the findings obtained from the opinions of Turkish teachers on the contribution of learning outcomes for listening defined in the MoNE Turkish course curriculum for the $6^{\text {th }}, 7^{\text {th }}$ and $8^{\text {th }}$ grades to the development creative thinking skills (CTS). 
Table 2. Teachers' opinions on the contribution of listening outcomes to the development of CTS

\begin{tabular}{|c|c|c|c|c|c|}
\hline & $\mathbf{N}$ & Minimum & Maksimum & $\mathrm{X}$ & Ss \\
\hline $\mathrm{k} 1$ & 150 & 1,00 & 5,00 & 3,85 & 1,06 \\
\hline $\mathrm{k} 2$ & 150 & 1,00 & 5,00 & 3,82 & 1,02 \\
\hline k3 & 150 & 1,00 & 5,00 & 4,08 & ,96 \\
\hline $\mathrm{k} 4$ & 150 & 1,00 & 5,00 & 3,99 &, 93 \\
\hline k5 & 150 & 1,00 & 5,00 & 4,16 &, 83 \\
\hline k6 & 150 & 1,00 & 5,00 & 4,18 &, 76 \\
\hline $\mathrm{k} 7$ & 150 & 1,00 & 5,00 & 4,22 & ,68 \\
\hline $\mathrm{k} 8$ & 150 & 1,00 & 5,00 & 4,24 &, 79 \\
\hline $\mathrm{k} 9$ & 150 & 1,00 & 5,00 & 4,16 &, 81 \\
\hline $\mathrm{k} 10$ & 150 & 1,00 & 5,00 & 4,24 &, 80 \\
\hline $\mathrm{k} 11$ & 150 & 1,00 & 5,00 & 4,24 &, 81 \\
\hline $\mathrm{k} 12$ & 150 & 1,00 & 5,00 & 4,18 &, 87 \\
\hline k13 & 150 & 1,00 & 5,00 & 4,22 &, 86 \\
\hline k14 & 150 & 1,00 & 5,00 & 4,19 &, 85 \\
\hline k15 & 150 & 1,00 & 5,00 & 4,33 &, 72 \\
\hline $\mathrm{k} 16$ & 150 & 1,00 & 5,00 & 4,24 &, 76 \\
\hline k17 & 150 & 1,00 & 5,00 & 4,17 &, 92 \\
\hline $\mathrm{k} 18$ & 150 & 1,00 & 5,00 & 4,34 & ,67 \\
\hline k19 & 150 & 1,00 & 5,00 & 4,47 & ,69 \\
\hline $\mathrm{k} 20$ & 150 & 1,00 & 5,00 & 4,46 &, 67 \\
\hline $\mathrm{k} 21$ & 150 & 1,00 & 5,00 & 4,39 &, 71 \\
\hline $\mathrm{k} 22$ & 150 & 1,00 & 5,00 & 4,46 & ,65 \\
\hline $\mathrm{k} 23$ & 150 & 1,00 & 5,00 & 4,34 & ,68 \\
\hline $\mathrm{k} 24$ & 150 & 1,00 & 5,00 & 4,36 & ,68 \\
\hline $\mathrm{k} 25$ & 150 & 1,00 & 5,00 & 4,31 &, 72 \\
\hline $\mathrm{k} 26$ & 150 & 1,00 & 5,00 & 4,09 &, 90 \\
\hline $\mathrm{k} 27$ & 150 & 1,00 & 5,00 & 4,30 &, 70 \\
\hline $\mathrm{k} 28$ & 150 & 1,00 & 5,00 & 4,24 &, 82 \\
\hline k29 & 150 & 1,00 & 5,00 & 3,68 & 1,07 \\
\hline $\mathrm{k} 30$ & 150 & 1,00 & 5,00 & 4,03 & ,90 \\
\hline k31 & 150 & 1,00 & 5,00 & 4,06 &, 89 \\
\hline $\mathrm{k} 32$ & 150 & 1,00 & 5,00 & 3,92 & 1,08 \\
\hline $\mathrm{k} 33$ & 150 & 1,00 & 5,00 & 4,27 &, 74 \\
\hline k34 & 150 & 1,00 & 5,00 & 4,20 &, 78 \\
\hline $\mathrm{k} 35$ & 150 & 1,00 & 5,00 & 3,82 & 1,10 \\
\hline k36 & 150 & 1,00 & 5,00 & 3,74 & 1,09 \\
\hline k37 & 150 & 1,00 & 5,00 & 4,15 &, 80 \\
\hline k38 & 150 & 1,00 & 5,00 & 4,03 &, 90 \\
\hline k39 & 150 & 1,00 & 5,00 & 4,07 &, 99 \\
\hline $\mathrm{k} 40$ & 150 & 1,00 & 5,00 & 4,09 & ,99 \\
\hline
\end{tabular}




\begin{tabular}{rrrrrr}
\hline $\mathrm{k} 41$ & 150 & 1,00 & 5,00 & 4,10 &, 93 \\
$\mathrm{k} 42$ & 150 & 1,00 & 5,00 & 3,82 & 1,12 \\
Overall average & 150 & 1,00 & 5,00 & 4,15 &, 57 \\
\hline
\end{tabular}

According to Table 2, teachers think that o1: "Listen the speaker patiently and respectfully without interrupting" $(\bar{X}=3.85)$, o2: "Listen/watch the speaker without disturbing the others" $(\bar{X}=3.82)$ and o4: "Use listening/watching methods and techniques" $(\bar{X}=3.99)$ contribute to the development of creative thinking skills. People with creative thinking skills are those that can communicate effectively. The answers of the teachers show that they agree with this opinion. The teachers' opinions on 03 : "Begin to speak to ask a question and express an opinion at the proper time" ( $\bar{X}=4.08)$ also show that they agree with the contribution of listening outcomes to creative thinking skills. Asking questions and expressing opinions are among the rules that need to be observed for proper communication. The teachers also expressed that they "Agree" with the contribution of o5: "Make sense of the words and phrases from the context of what they have listened to/watched" $(\bar{X}=4.16)$ and o6: "Recognize the key words in what have listened to/watched" $(\bar{X}=4.18)$ to creative thinking skills.

The ability to make sense of the words and phrases from the context of a text and to recognize the key words in texts is an important factor that develops creative thinking skills. On completion of these outcomes, student will try to come to their own conclusions by analyzing instead of merely receiving learning passively. To do this, they will need to understand a passage and interpret it. By means of this activity, students can have the opportunity to improve themselves.

The teachers expressed that they "Strongly agree" with the contribution of o7: "Determine the subject of what they have listened to" $(\bar{X}=4.22)$ to the development of creative thinking skills. Similarly, they "Strongly agreed" that 08: "Find the main idea of what they have listened to" $(\bar{X}=4.24)$ contributes to creative thinking skills.

The teachers expressed that they "Strongly agree" with the contribution of o10: "Find the plot, place, time, characters, entities and the related elements in what they have listened to/watched" ( $\bar{X}=4.24)$ and o11: "Find the cause and effect relations in what they have listened to/watched" $(\bar{X}=4.24)$ to the development of creative thinking skills. They also "Agreed" with the contribution of o12: "Find the purpose-effect relations in what they have listened to/watched" $(\bar{X}=4.18)$ to creative thinking skills.

The teachers expressed that they "Agree" with the contribution of o9: "Find the supporting ideas/senses in what they have listened to/watched" $(\bar{X}=4.16)$ and o14: "Summarize what they have listened to/watched in a logical and chronological order" ( $\bar{X}=4.19)$ to the development of creative thinking skills.

The teachers also "Strongly agreed" that o13: "Find the implicit meaning in what they have listened to/watched" $(\bar{X}=4.22)$, o15: "Ask questions about what they have listened to/watched" $(\bar{X}=4.33)$ and o16: "Answer the questions about what they have listened to/watched" $(\bar{X}=4.24)$ contribute to the development of creative thinking skills.

They also expressed that they "Strongly agree" with the contribution of o18: "Make comparisons in the context of what they have listened to/watched" $(\bar{X}=4.34)$, o19: "Interpret the emotions, ideas and dreams by putting themselves in the shoes of the characters and other elements" $(\bar{X}=4.47)$, o20: "Find different solutions to the problems mentioned in what they have listened to/watched" $(\bar{X}=4.46)$, o21: "Make predictions about what they have listened to/watched based on the clues" $(\bar{X}=4.39)$ and 022 : "Set up what happens before and after what they have listened to/watched." $(\bar{X}=4.46)$ to the development of creative thinking skills.

The teachers "Agreed" that o17: "Recognize the subjective and objective judgements in what they have listened to/watched." ( $\bar{X}=4.17)$ contributes to the development of creative thinking skills.

The teachers also expressed that they "Strongly agree" with the contribution of o23: "Find the relationship between the title/name and content of what they have listened to/watched." $(\bar{X}=4.34)$, o24: "Find different titles to the passage they have listened to/watched." $(\bar{X}=4.36)$, and 025 : "Establish relationship between visual/audio elements and what they have listened to/watched." $(\bar{X}=4.31)$ to the development of creative thinking skills.

They also "Strongly agreed" that 027 : "Express the feelings they get after reading a poem." $(\bar{X}=4.30)$ and o28: "Compares what they have listened to/watched with their everyday lives." ( $\bar{X}=4.24)$ contribute to the development of creative thinking skills. 
The teachers also expressed that they "Agree" with the contribution of 026 : "Distinguish the difference of poetic language." $(\bar{X}=4.09)$ and o29: "Obtain information about the characters, topic or author/poet of what they have listened to/watched." ( $\bar{X}=3.68)$ to the development of creative thinking skills.

The teachers expressed that they "Agree" with the contribution of o30: "Assess what they have listened to/watched in terms of language and expression." $(\bar{X}=4.03)$, 031: "Assess what they have listened to/watched in terms of content." $(\bar{X}=4.06)$ and 032 : "Assess the speaker's use of the tone of voice and body language." $(\bar{X}=3.92)$ to the development of creative thinking skills.

They also "Strongly agreed" that o33: "Comprehend the semantic relations among words and give examples of semantically related words." $(\bar{X}=4.27)$ and 034 : "Use the words in the same conceptual field by taking account of semantic differences." $(\bar{X}=4.20)$ contribute to the development of creative thinking skills.

The teachers expressed that they "Agree" with the contribution of $\mathrm{o} 35$ : "Use the puzzling descriptions of nursery rhymes and riddles" ( $(\bar{X}=3.82)$ and 036 : "Memorizes poetic expressions such as poems, folk songs and songs." $(\bar{X}=3.74)$ to the development of creative thinking skills. They also "Agreed" that o37: "Use the words, idioms and proverbs in what they have listened to/watched in a sentence" $(\bar{X}=4.15)$ contributes to the development of creative thinking skills.

The teachers also stated that they "Agree" with the contribution of o38: "Add the new words to their personal lexicon based on what they have listened to/watched." $(\bar{X}=4.03)$ and o39: "Participate in art and science activities appropriate to their age and level." $(\bar{X}=4.07)$ to the development of creative thinking skills.

They also expressed that they "Agree" with the contribution of 040 : "Participate in poem, story and fairy tale recitals." ( $\bar{X}=4.09)$ and 041 : "Follow what they need and want to do." $(\bar{X}=4.10)$ to the development of creative thinking skills. They also "Agreed" that 042 : "Create a personal archive of cassettes, CDs, movies etc." $(\bar{X}=3.82)$ contributes to the development of creative thinking skills.

The following are the findings regarding the question "Do the opinions of Turkish teachers on the contribution of learning outcomes for listening defined in the MoNE Turkish course curriculum for the $6^{\text {th }}, 7^{\text {th }}$ and $8^{\text {th }}$ grades to the development of creative thinking skills change depending on gender, seniority, alma mater and educational background?"

\section{a) Gender}

Table 3 shows the findings regarding the teachers' opinions on the contribution of listening outcomes to the CTS based on their gender.

Table 3. Turkish teachers' opinions on the creative thinking skills based on their gender

\begin{tabular}{|c|c|c|c|c|c|c|c|}
\hline & & Strongly Disagree & Disagree & Neutral & Agree & Strongly Agree & Total \\
\hline & $\mathrm{f}$ & 0 & 0 & 4 & 34 & 41 & 79 \\
\hline \multicolumn{8}{|c|}{ Male } \\
\hline & $\%$ & $0.0 \%$ & $0.0 \%$ & $5.1 \%$ & $43.0 \%$ & $51.9 \%$ & $100.0 \%$ \\
\hline \multicolumn{8}{|l|}{ Gender } \\
\hline & $\mathrm{f}$ & 1 & 1 & 5 & 34 & 30 & 71 \\
\hline \multicolumn{8}{|c|}{ Female } \\
\hline & $\%$ & $1.4 \%$ & $1.4 \%$ & $7.0 \%$ & $47.9 \%$ & $42.3 \%$ & $100.0 \%$ \\
\hline & $\mathrm{f}$ & 1 & 1 & 9 & 68 & 71 & 150 \\
\hline \multicolumn{8}{|l|}{ Total } \\
\hline & $\%$ & $0.7 \%$ & $0.7 \%$ & $6.0 \%$ & $45.3 \%$ & $47.3 \%$ & $100.0 \%$ \\
\hline
\end{tabular}

According to Table 3, most of the teachers agree that listening outcomes contribute to the development of creative thinking skills. $45.3 \%$ of the teachers showed a high level of agreement with the contribution of listening outcomes to creative thinking skills, while $47.3 \%$ showed a very high level of agreement. The table also shows that $43 \%$ of the male teachers showed a high level of agreement with the listening outcomes' contribution 
to creative thinking skills, while $51.9 \%$ showed a very high level of agreement. $47.9 \%$ of the female teachers showed high level agreement with the contribution of listening outcomes to creative thinking skills, while $42.3 \%$ showed very high level agreement.

Table 4 shows the results of the chi-square test regarding the contribution of listening outcomes of the Turkish course to the development of creative thinking skills based on the genders of participants.

Table 4. The results of the Chi-Square Test based on the genders of Turkish teachers

\begin{tabular}{cccc}
\hline & Value & Ss & P \\
\hline Chi-Square $(\chi 2)$ & $3.398^{\mathrm{a}}$ & 4 & .494 \\
Likelihood Ratio & 4.168 & 4 & .384 \\
Linear Association & 2.721 & 1 & .099 \\
$\mathbf{N}$ & 150 & & \\
\hline
\end{tabular}

The results of the Chi-Square test conducted to determine whether there is a difference between the opinions of Turkish teachers on the contribution of listening outcomes to the development of CTS based on gender show that there is no significant difference in the opinions based on gender $(\chi 2(4)=.494, \mathrm{p}>0.05)$.

\section{b) Length of Service (Seniority)}

Table 5 shows the opinions of Turkish teachers on the contribution of listening outcomes of the Turkish course to the development of creative thinking skills based on their length of service.

Table 5. Opinions of Turkish teachers based on their length of service

\begin{tabular}{|c|c|c|c|c|c|c|c|c|}
\hline & & & $\begin{array}{l}\text { Strongly } \\
\text { Disagree }\end{array}$ & Disagree & Neutral & Agree & $\begin{array}{c}\text { Strongly } \\
\text { Agree }\end{array}$ & Total \\
\hline \multirow{6}{*}{$\begin{array}{l}\text { Length of } \\
\text { Service }\end{array}$} & \multirow{2}{*}{$1-5$} & $f$ & 0 & 0 & 5 & 8 & 15 & 28 \\
\hline & & $\%$ & $0.0 \%$ & $0.0 \%$ & $17.9 \%$ & $28.6 \%$ & $53.6 \%$ & $100.0 \%$ \\
\hline & \multirow{2}{*}{$6-15$} & $f$ & 0 & 0 & 3 & 31 & 31 & 65 \\
\hline & & $\%$ & $0.0 \%$ & $0.0 \%$ & $4.6 \%$ & $47.7 \%$ & $47.7 \%$ & $100.0 \%$ \\
\hline & \multirow{2}{*}{$\begin{array}{l}16 \text { years and } \\
\text { above }\end{array}$} & $f$ & 1 & 1 & 1 & 29 & 25 & 57 \\
\hline & & $\%$ & $1.8 \%$ & $1.8 \%$ & $1.8 \%$ & $50.9 \%$ & $43.9 \%$ & $100.0 \%$ \\
\hline \multirow{2}{*}{\multicolumn{2}{|c|}{ Total }} & $\mathrm{f}$ & 1 & 1 & 9 & 68 & 71 & 150 \\
\hline & & $\%$ & $0.7 \%$ & $0.7 \%$ & $6.0 \%$ & $45.3 \%$ & $47.3 \%$ & $100.0 \%$ \\
\hline
\end{tabular}

Table 5 shows that most of the teachers with a length of service of 16 years and above agreed with the contribution of listening outcomes to the development of creative thinking skills. Of all teachers, $45.3 \%$ showed a high level of agreement with the contribution of outcomes to the relevant skills, while $47.3 \%$ showed a very high level of agreement. The table also shows that $28.6 \%$ of the teachers with a length of service from 1 to 5 years showed a high level agreement with the contribution of these outcomes to creative thinking skills, while $53.6 \%$ showed a very high level agreement. Out of the teachers with a length of service from 6 to 15 years, $47.7 \%$ showed a high level agreement with such contribution, while $47.7 \%$ showed a very high level agreement. Moreover, out of the teachers with a length of service of 16 years and above, 50.9\% showed a high level agreement with such contribution, while $43.9 \%$ showed a very high level agreement.

Table 6 shows the results of the chi-square test regarding the contribution of listening outcomes of the Turkish course to the development of creative thinking skills based on the length of service of the participants. 
Table 6. The results of the Chi-Square Test based on the length of service of Turkish teachers

\begin{tabular}{cccc}
\hline & Value & Ss & p \\
\hline Chi-Square $(\chi 2)$ & $14.323^{\mathrm{a}}$ & 8 & .074 \\
Likelihood Ratio & 13.565 & 8 & .094 \\
Linear Association & .107 & 1 & .743 \\
$\mathbf{N}$ & 150 & & \\
\hline
\end{tabular}

The results of the Chi-Square test conducted to determine whether there is a difference between the opinions of Turkish teachers on the contribution of listening outcomes to the development of CTS based on the length of service show that there is no significant difference in the opinions based on the length of service of the participants $(\chi 2(8)=.074, \mathrm{p}>0.05)$.

c) Alma Mater

Table 7 shows the opinions of Turkish teachers on the contribution of listening outcomes of the Turkish course to the development of creative thinking skills based on their alma mater.

Table 7. Opinions of Turkish teachers based on their alma mater

\begin{tabular}{|c|c|c|c|c|c|c|c|c|}
\hline & & & $\begin{array}{l}\text { Strongly } \\
\text { Disagree }\end{array}$ & Disagree & Neutral & Agree & $\begin{array}{c}\text { Strongly } \\
\text { Agree }\end{array}$ & Total \\
\hline \multirow{8}{*}{ Department } & $\begin{array}{l}\text { Turkish Language } \\
\text { Teaching }\end{array}$ & $\mathrm{f}$ & 0 & 0 & 7 & 34 & 43 & 84 \\
\hline & & $\%$ & $0.0 \%$ & $0.0 \%$ & $8.3 \%$ & $40.5 \%$ & $51.2 \%$ & $100.0 \%$ \\
\hline & Turkish Language and & $\mathrm{f}$ & 0 & 0 & 1 & 6 & 7 & 14 \\
\hline & Literature Teaching & $\%$ & $0.0 \%$ & $0.0 \%$ & $7.1 \%$ & $42.9 \%$ & $50.0 \%$ & $100.0 \%$ \\
\hline & $\begin{array}{l}\text { Turkish Language and } \\
\text { Literature }\end{array}$ & $\mathrm{f}$ & 1 & 1 & 1 & 28 & 21 & 52 \\
\hline & & $\%$ & $1.9 \%$ & $1.9 \%$ & $1.9 \%$ & $53.8 \%$ & $40.4 \%$ & $100.0 \%$ \\
\hline & & $\mathrm{f}$ & 1 & 1 & 1 & 9 & 68 & 71 \\
\hline & Total & $\%$ & $0.7 \%$ & $0.7 \%$ & $0.7 \%$ & $6.0 \%$ & $45.3 \%$ & $47.3 \%$ \\
\hline
\end{tabular}

Table 7 reveals that most of the participants agreed with the contribution of listening outcomes to the development of creative thinking skills. Of all teachers, $6 \%$ showed a high level of agreement with the contribution of outcomes to the relevant skills, while $45.3 \%$ showed a very high level of agreement. The table also shows that $40.5 \%$ of the graduates of Turkish Language Teaching showed a high level agreement with the contribution of these outcomes to creative thinking skills, while $51.2 \%$ showed a very high level agreement. Out of the graduates of Turkish Language and Literature Teaching, $42.9 \%$ showed a high level agreement with such contribution, while $50 \%$ showed a very high level agreement. Moreover, out of the graduates of Turkish Language and Literature, $53.8 \%$ showed a high level agreement with such contribution, while $40.4 \%$ showed a very high level agreement.

Table 8 shows the results of the chi-square test regarding the contribution of listening outcomes of the Turkish course to the development of creative thinking skills based on the alma mater of the participants. 
Table 8. The results of the Chi-Square Test based on the alma mater of Turkish teachers

\begin{tabular}{cccc}
\hline & Value & Ss & P \\
\hline Chi-Square $(\chi 2)$ & $8.105^{\mathrm{a}}$ & 8 & .423 \\
Likelihood Ratio & 9.002 & 8 & .342 \\
Linear Association & 1.264 & 1 & .261 \\
$\mathbf{N}$ & 150 & & \\
\hline
\end{tabular}

The results of the Chi-Square test conducted to determine whether there is a difference between the opinions of Turkish teachers on the contribution of listening outcomes to the development of CTS based on the alma mater of the participants show that there is no significant difference in the opinions based on the alma mater $(\chi 2(8)=.423, \mathrm{p}>0.05)$.

\section{d) Educational Background}

Table 9 shows the opinions of Turkish teachers on the contribution of listening outcomes of the Turkish course to the development of creative thinking skills based on their educational background.

Table 9. Opinions of Turkish teachers based on their educational background

\begin{tabular}{|c|c|c|c|c|c|c|c|c|}
\hline & & & Strongly Disagree & Disagree & Neutral & Agree & Strongly Agree & Total \\
\hline \multirow[b]{2}{*}{ Educational } & \multirow[b]{2}{*}{ Undergraduate } & $\mathrm{f}$ & 1 & 1 & 7 & 61 & 67 & 137 \\
\hline & & $\%$ & $0.7 \%$ & $0.7 \%$ & $5.1 \%$ & $44.5 \%$ & $48.9 \%$ & $100.0 \%$ \\
\hline \multirow[t]{2}{*}{ Background } & & $\mathrm{f}$ & 0 & 0 & 2 & 7 & 4 & 13 \\
\hline & Graduate & $\%$ & $0.0 \%$ & $0.0 \%$ & $15.4 \%$ & $53.8 \%$ & $30.8 \%$ & $100.0 \%$ \\
\hline \multirow{2}{*}{\multicolumn{2}{|c|}{ Total }} & $\mathrm{f}$ & 1 & 1 & 1 & 9 & 68 & 71 \\
\hline & & $\%$ & $0.7 \%$ & $0.7 \%$ & $0.7 \%$ & $6.0 \%$ & $45.3 \%$ & $47.3 \%$ \\
\hline
\end{tabular}

Table 9 reveals that most of the participants agreed with the contribution of listening outcomes to the development of creative thinking skills. Of all teachers, $6.0 \%$ showed a high level of agreement with the contribution of outcomes to the relevant skills, while $45.3 \%$ showed a very high level of agreement. The table also shows that $44.5 \%$ of the teachers with an undergraduate degree showed a high level agreement with the contribution of these outcomes to creative thinking skills, while $48.9 \%$ showed a very high level agreement. Out of the teachers with a graduate degree, 53.8\% showed a high level agreement with such contribution, while $30.8 \%$ showed a very high level agreement.

Table 10 shows the results of the chi-square test regarding the contribution of listening outcomes of the Turkish course to the development of creative thinking skills based on the educational background of the participants.

Table 10. The results of the Chi-Square Test based on the educational background of Turkish teachers

\begin{tabular}{cccc}
\hline & Value & Ss & p \\
\hline Chi-Square $(\chi 2)$ & $3.332^{\mathrm{a}}$ & 4 & .504 \\
Likelihood Ratio & 3.027 & 4 & .553 \\
Linear Association & 1.520 & 1 & .218 \\
$\mathbf{N}$ & 150 & & \\
\hline
\end{tabular}

The results of the Chi-Square test conducted to determine whether there is a difference between the opinions of Turkish teachers on the contribution of listening outcomes to the development of CTS based on the educational 
background of the participants show that there is no significant difference in the opinions based on the educational background $(\chi 2(4)=.504, \mathrm{p}>0.05)$.

\subsection{Findings of the Qualitative Data}

The following categories were identified as a result of the interviews held with the teachers about their opinions on the contribution of listening outcomes defined in the Turkish course curriculum for the $6^{\text {th }}, 7^{\text {th }}$ and $8^{\text {th }}$ grade students to the development of creative thinking skills:

- Listening outcomes and creativity

- Creative thinking

- Readiness level of students

- Development of thinking skills

\subsubsection{Listening Outcomes and Creativity}

As one of the four basic language skills, listening is important for the students to develop creative thinking skills. The learning outcomes for listening both improve the students' skills and encourage them to think creatively. Creative thinkers are expected to come up with new ideas. On completion of these outcomes, students will be able to come up with new and different ideas. According to the opinions of teachers, the learning outcomes for listening help students think multidimensionally and avoid rote-learning, just like the outcomes for reading, speaking and writing. The opinion of TE1, one of the teachers, on this issue was as follows:

"Students can come up with new and different ideas on completion of the learning outcomes for listening. One of them is to make a guess about what happens before and after a passage. I ask students to make a guess about what happens before and after a passage. They come up with different ideas upon achievement of this outcome." TE1

\subsubsection{Creative Thinking}

Creative thinking involves taking advantage of the problems, trying different solutions for these problems and coming up with new ideas. Those with creative thinking skills gain an important place in society. Since they are quick-minded and have leadership qualities, they are always appreciated by the people around them.

All the participants indicated that they considered creative thinking to be coming up with a new product. Most of the teachers viewed creative thinking as finding new solutions to the problems. In short, creative thinking was defined by the teachers as coming up with a new product, looking at problems from a different perspective and finding differences by relating the past with the future. TK3's opinion on this issue was as follows:

"Creative thinking involves students finding solutions to an issue or problem from their own perspective, showing new approaches based on a text or coming up with their own products." TK3

\subsubsection{Readiness Level of Students}

Readiness refers to a student's review of previously learned information before receiving new information. It involves the review of the previously learned information about a subject, and interpretation of what could be done with the new information. Creative thinking involves students completing the thoughts and entering into details. While entering into details, they come up with new ideas. Students must have prior knowledge of the subject in order to think in detail. Therefore, teachers ask them questions that can activate their prior knowledge of the relevant topic and encourage them to relate new information to existing knowledge.

During the interviews, half of the teachers stated that they probed the students' prior knowledge before reading a passage and defined the learning outcomes based on the passage. They also indicated that they acted in accordance with the outcomes appropriate for both the passage and the students. The teachers who did not look at the events from a single point of view took both the passage and the students into account. TE7's opinion on this issue was as follows:

"The most important factor that helped me chose the outcomes are the relationships established by the students between the existing and new knowledge. If the students are not able to establish intertextual relations, then I first remind them of the previous passage and measure their readiness level. After reminding them of their prior knowledge in a question and answer format, I read the new passage and expect them to relate it with the previous one. Then I write down the outcome as 'Students will be able to make comparisons about what they have listened to'." TE7 


\subsubsection{Development of Thinking Skills}

The participants of this study indicated that "critical thinking" and "reflective thinking skills" were also included in the learning outcomes for listening. Based on their opinions, one of these outcomes is "Interpret the emotions, ideas and dreams by putting themselves in the shoes of characters and other elements" and the other one is "Compares what they have listened to/watched with their life and daily life".

Just like creative thinking skills, critical and reflective thinking skills are among the higher-order thinking skills. Students with critical thinking skills look at the events from both positive and negative perspectives. They sort out useful information and make interpretations about the other information. At this stage, they can find deficiencies as well as coming up with new ideas. If we expect students to produce new and original ideas, we should first reveal their critical thinking skills. Reflective thinking skills involve students applying what they have learned to everyday life and learning lessons from the past. Students are expected to learn from their own experiences, find their mistakes and share the lessons they have learned with other people. The explanations given above reveal the importance of reflective and critical thinking. Gencel and Candan (2014) indicated that critical thinking tendency and reflective thinking skills were effective in the quality of teachers and the teaching-learning process.

The participants of this study said that students would able to develop themselves on completion of these outcomes. TE5's opinion on this issue was as follows:

"The learning outcomes for listening help students improve their critical thinking skills. The students can gain insight about what is right or wrong by putting themselves in the shoes of the characters in a passage. In this way, they can also do self-criticism." TE5

\section{Conclusion and Discussion}

The findings of this study show that the opinions of Turkish teachers about the contribution of listening outcomes defined in the Turkish course curriculum for $6^{\text {th }}, 7^{\text {th }}$ and $8^{\text {th }}$ grade students to the development of creative thinking skills do not change depending on gender, seniority, alma mater and educational background. All teachers agreed that the listening outcomes defined in the MoNE Turkish course curriculum contributed to the development of creative thinking skills. The findings provide a proof that the outcomes are designed in a way to be useful for the students. Although teachers found the outcomes in the Turkish course curriculum sufficient, it is still recommended that they be developed.

In this study, interviews were held to receive the opinions of Turkish teachers on the contribution of listening outcomes defined in the MoNE Turkish course curriculum for $6^{\text {th }}, 7^{\text {th }}$ and $8^{\text {th }}$ grade students to the development of creative thinking skills. The following categories were identified as a result of the interviews: 1) Listening outcomes and creativity, 2) Creative thinking, 3) Readiness level of students, 4) Development of thinking skills. The striking finding of this study is that the learning outcomes for listening contribute to the development of creative thinking skills, but the classroom activities are not enough. The activities identified in the curriculum or course books must be prepared and enriched by the curriculum developers and specialists in a way to allow for the achievement of these outcomes. Besides, the learning outcomes for listening must be more comprehensive than those for reading, writing and speaking skills, because there are not different outcomes that separate these four skills. We believe that it will help students improve themselves more, if the outcomes for listening are designed more comprehensively and focus is given to concrete examples. In this way, student will be able to come up with different ideas against the problems based on the passages. Listening passages are not included in the workbooks of the student, which is important in helping them develop their creative thinking skills. In this way, they will be able to make comments on a passage and predict what will happen at the end of it. Therefore, listening passages in the course books must be chosen from daily life, so that students will be able to put themselves in the shoes of the characters in a passage and compare the events in a passage with real-life events.

Individuals with creative thinking skills share their knowledge with others and easily ask what they are curious about. Moreover, they do not look at the events from a single point of view since they want to find solutions to the problems. Individuals looking at events from a multidimensional perspective do not experience the problem of functional fixedness, the biggest obstacle to creative thinking skills. Such people try to do something new and different with what they have.

Based on these, we can say that the learning outcomes for listening contribute to the development of creative thinking skills. The responses given by the teachers are in conformity with our opinion. On completion of these outcomes, students will be able to improve their creative thinking skills and question their lives. Such questioning provides a proof that the learning outcomes have served their purpose. 


\section{References}

Alkan, C., Deryakulu, D., \& Şimşek, N. (1995). Eğitim Teknolojisine Giriş (Introduction to Educational Technology). Ankara.

Erdem, E., \& Demirel, Ö. (2002). Program Gelişstirmede Yapılandırmacılık Yaklaşımı (Construtivism in Curriculum Development) (p. 23, pp. 81-87). Hacettepe Üniversitesi Eğitim Fakültesi Dergisi.

Evin Gencel, İ., \& Güzel Candan, D. (2014). Öğretmen adaylarının Eleştirel Düşünme Eğilimleri ve Yansıtıcı Düşünme Düzeylerinin İncelenmesi (Investigation of Critical Thinking Tendency and Reflective Thinking Levels of Teacher Candidates). Uluslararası Eğitim Programları Ve Öğretim Çalışmaları Dergisi, 4(8).

Güneş, F. (2011). Dil Öğretim Yaklaşımları ve Türkçe Öğretimindeki Uygulamalar (Language Teaching Approaches and Their Applications in Teaching Turkish). Mustafa Kemal Üniversitesi, 8(15), 123-148.

Karasar, N. (2002). Bilimsel Araştırma Yöntemi (Scientific Research Method). Ankara: Nobel Kitabevi.

MEB. (2006). Illköğretim Türkçe Dersi Öğretim Programı ve Kılavuzu (6-8. Sinıflar) (Elementary Turkish Course Curriculum and Guide [for the $6^{\text {th }}, 7^{\text {th }}$, and $8^{\text {th }}$ grades]). Ankara: Devlet Kitapları Müdürlügü Basımevi.

MEB. (2009). Illköğretim Türkçe Dersi Öğretim Programı ve Kılavuzu (1-5. Sinıflar) (Elementary Turkish Course Curriculum and Guide [Grades 1 to 5]). Ankara: Devlet Kitapları Müdürlüğ̈̈ Basımevi.

Özbay, M. (2009). Dinleme Eğitimi (Listening Training). Ankara: Öncü Basımevi.

Özden, Y. (2000). Öğrenme ve Öğretme (Learning and Teaching). Ankara: Pegem A Yayınları.

Özel, A., \& Bayındır, N. (2008). Yapılandırmacıllk anlayışa Göre Sinıf Yönetimi (Class Management Based on Constructivism) (1st ed.). Ankara: Pegem Akademi.

San, İ. (1979). Sanatta Yaratma, Çocukta Yaratıcllk (Creativity in Art, Creativity in Children) (2nd ed.). Ankara: Türkiye İş Bankası Yayınları.

Senemoğlu, N. (2001). "Öğrenme Ürünleri ve Eğitimi” (Learning Products and Training). MoNE Projects Coordination Center. İlkögretimde Etkili Öğretme ve Öğrenme Öğretmen El Kitabl (Teacher's Handbook for Effective Teaching and Learning in Primary Education). Modül 2 (Module 2).

Şaşan, H. H. (2002). Yapılandırmacı Öğrenme (Constructivist Learning). Yaşadıkça Eğitim, 49-52.

Tekin, M., \& Taşgın, Ö. (2008). Orta öğretimde öğrenim gören spor yapan ve yapmayan öğrencilerin yaratıcılık ve çoklu zekâ alanları arasındaki ilişkinin incelenmesi. Niğde Üniversitesi, Beden Eğitimi ve Spor Bilimleri Dergisi, 2(3), 207.

Ünalan, Ş. (2001). Türkçe öğretimi (Teaching Turkish) (2nd ed.). Ankara: Nobel.

Yenilmez, K., \& Yolcu, B. (2007). Öğretmen Davranışlarının Yaratıcı Düşünme Becerilerinin Gelişimine Katkı1 (Contributions of Teachers' Behaviors on Creative Thinking Abilities). Sosyal Bilimler Dergisi, 18, 95-105.

Yıldırım, A., \& Şimşek, H. (2006). Sosyal Bilimlerde Nitel Araştırma Yöntemleri (Qualitative Research Methods in Social Sciences) (6th ed.). Ankara: Seçkin Yayıncılık.

\section{Note}

Note 1. This study "Contribution of Grade 6 to 8 Turkish Course Listening Acquasitions to the Creative Thinking Skills According to the Teachers Opinions" cited from master's thesis, prepared by E. Aldı ̆ in consultation A. Arseven.

\section{Copyrights}

Copyright for this article is retained by the author(s), with first publication rights granted to the journal.

This is an open-access article distributed under the terms and conditions of the Creative Commons Attribution license (http://creativecommons.org/licenses/by/4.0/). 